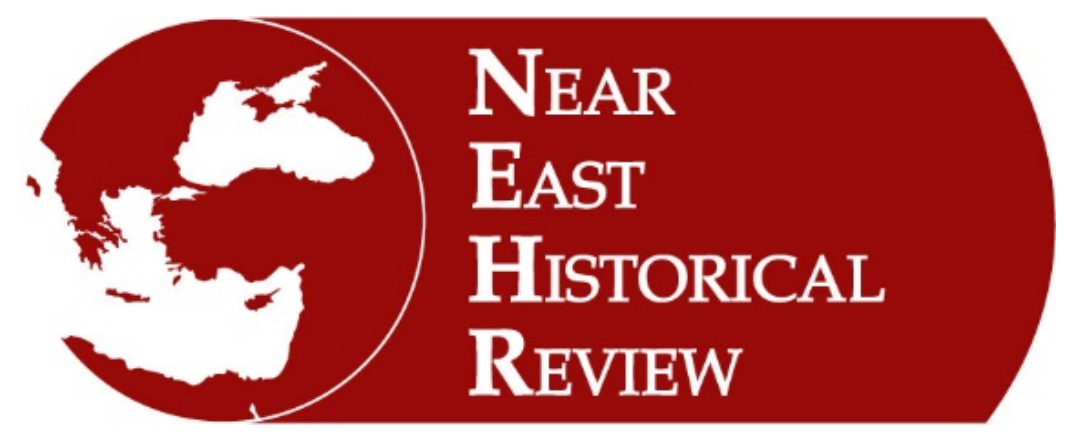

\title{
Suriye Vilayetinde Modernleşme Sanc1sı Hakkında Bir Rapor
}

A Report on The Modernization Discomfort in Syria Province

\author{
Assoc. Prof. Dr. Abidin Temizer - Selman Ekici \\ Burdur Mehmet Akif Ersoy Üniversitesi - Ankara İl Milli Eğitim Müdürlüğü, Türkiye \\ e-mail: abidintemizer@hotmail.com \\ ORCID ID: https:// orcid.org/ 0000-0001-5708-3132 / https://orcid.org/0000-0003-1922-5552
}

Near East Historical Review
10/1, January - Ocak 2020 e-ISSN: 2717-6363 (Online)
www.nehrreview.com

$\begin{array}{rll}\text { Article Type Makale Türü : } & \text { Research Article } \\ \text { Received Date-Geliş Tarihi }: & \mathbf{3 1 . 1 2 . 2 0 1 9} \\ \text { Accepted Date-Kabul Tarihi }: & \mathbf{2 4 . 0 1 . 2 0 2 0} \\ \text { Pages - Sayfa }: & \mathbf{4 7 - 5 8} \\ \text { doi }: & \text { http://dx.doi.org/10.29228/nehrreview.41555 }\end{array}$

Citation-Atuf : Abidin Temizer - Selman Ekici, "Suriye Vilayetinde Modernleşme Sancısı Hakkında Bir Rapor", Near East Historical Review, 10/1, January 2020, ss. 4758. 



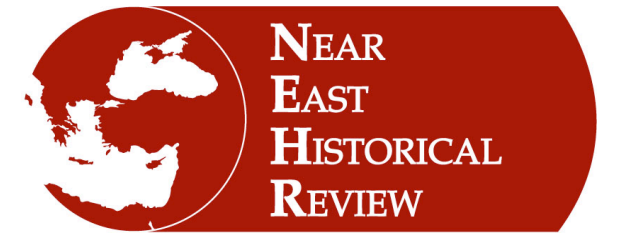

Near East Historical Review

10/1, January - Ocak 2020

$47-58$

\title{
Suriye Vilayetinde Modernleşme Sancısı Hakkında Bir Rapor \\ A Report on The Modernization Discomfort in Syria Province
}

\author{
Doç. Dr. Abidin Temizer - Selman Ekici \\ Burdur Mehmet Akif Ersoy Üniversitesi, Türkiye / Milli Eğitim Bakanlığı, Türkiye
}

Öz

$\mathrm{Bu}$ makalenin amacı Osmanlı modernleşmesini taşradan merkeze gönderilen raporlar üzerinden okumaya yardımcı olmaktır. Merkezi otoritenin boşluğunu doldurmaya çalışan yerel güçler modernleşmenin önünde en büyük dirençlerden birini oluşturdular. Kendi aralarında hukuksuzluk üzerine ittifak ettiler. Görevini yapanları pasif konuma getirdiler. Çalışmamız Osmanlı taşrasında yaşanan bu sürece Suriye Vilayeti örneğinde bir raporla 1 şı tutmaktadır.

Anahtar Kelimeler: Osmanlı Devleti, Suriye Vilayeti, Modernleşme, Yerel Güçler

\section{Abstract}

This article aims to facilitate reading the Ottoman modernization through the reports sent from the provinces to the center. The local forces, which tried to fill the vacuum of the central authority, constituted one of the biggest resistance against modernization. They allied among themselves on unjustness. They assigned those who duly performed their duties to passive positions. Our study sheds light on this process in the Ottoman provinces with a report in the case of the Syrian Province.

Keywords: Ottoman Empire, Syria Province, Modernization, the local forces 


\section{Giriş}

19. yüzyıl Suriye limanları Batılı devletlerin ticari endişeleri dolayısıyla öne çıkmıştı. Bölgenin ticari ehemmiyetinin yanında tarımsal değerlerindeki gelişmeler küresel eklemleşmeyi hızlandırmıştı. Bu durum kültürel, siyasi ve kurumsal değişimi kaçınılmaz kılmıştı. ${ }^{1}$

Ulaşım ve haberleşme ağlarının gelişmesi Suriye ahalisinin başta Amerika olmak üzere kıtalararası göçlerini de tetikledi. Binlerce Suriyeli ve Lübnanlı Amerika'ya göç etti. ${ }^{2}$ Bununla birlikte özellikle Fransız işgali sonrasında Cezayir'den gelen muhacirlerin büyük çoğunluğu Suriye'ye yerleştiler. Başta asayiş olmak üzere bazı sorunları beraberinde getiren bu göçler Suriye'nin sosyal ve politik yapısında değişimlere yol açtı. ${ }^{3}$

19. yüzyılda Osmanlı idaresi yaptırdığı incelemeler veya bölgeden gelen raporlarla Suriye hakkında bilgi topluyor, politikalar üretiyordu. Bu raporlardan birisi de "Suriye vilayetinin mali işleri hakkında bir layiha sureti” adıyla Devlet Arşivleri Osmanlı Arşivi Yıldız Esas Evrakı Yıldız Esas Evrakı fonu içerisinde 33/114 gömlek ve sıra nosuyla kayıtlı olup, 10 Aralık 1875 (12 Zilkade 1292) tarihlidir.

\section{Suriye Vilayetinde Devletin İşleyişi}

Söz konusu raporun kaleme alınma gayesi, Suriye Vilayetinin geniş ve verimli topraklara sahip olmasına rağmen kanunların uygulanmaması, memurların maaşlarının ödenememesi, üretimin arttırılamaması, devlet gelirlerinin büyük kısmının zimmete geçirilmesi gibi nedenlerle bozulan gelir gider dengesi ve maliyesinin yeniden tesis edilmesi ve düzenlenmesine yöneliktir.

Raporda Suriye Vilayetinin mali yapısının düzeltilmesine dair öneriler kapsamında, gelir ve gider dengesinin bozulmasının sebepleri, gelir ve gider dengesinin sağlanması, harcamaların kontrol altına alınması ve görevlerini layıkıyla yerine getiren memurların ödüllendirilmesine yönelik tespit ve öneriler ifade edilmektedir.

Raporun birinci bölümünde, yüz otuzdan fazla köy ve mezranın öşür ve vergilerinin gizlendiği, bunlar hakkında vilayetin ve hazinenin bilgisi dahi olmadığ iddia ediliyordu. Herhangi bir araştırma yapılmayarak gelirlerin azalma sebeplerinin incelenmediği, bununla birlikte düşük maaşla bakayanın mevcudiyetinin tespit edilemeyeceği ifade ediliyordu. Memur maaşlarının iyileştirilmesi halinde hazine gelirlerinin de artacağı vurgulanıyordu.

Suriye Vilayetinin idaresi hakkında da önemli bilgiler sunulmaktaydı. Rapora göre vilayet idaresi usulüne uygun defter tutmuyordu. Vilayetin gelir ve giderlerinin doğru bir şekilde tespit edilmesi ve yazılmasına gerek görülmüyordu. Var olan belgelerin doğruluğu da tartışmalıydı. Memurlar, görev devir ve tesliminde kurallara uymuyor, muhasebe ve mal sandıklarının kayıtlarını haleflerine teslim etmiyorlardı. Muhasebe ve mal sandıklarına ait yevmiye defterlerine yazılan gelir-giderler de tutarlı değildi. Üstelik bu defterler mal müdürleri yerine sandık eminlerince, yani yetkisiz kişilerce onaylanıyordu.

Sandık eminleri sandıklara teslim edilen akçeler için mal memurlarının işareti ve mührü olmaksızın mühürlü mühürsüz niteliksiz makbuz pusulası veriyordu. Bazı ödeneklerden izin alınmaksızın harcama yapılıyordu. Mal memurlarınca izinsiz harcanan paraların toplamının on

\footnotetext{
${ }^{1}$ İlber Ortaylı, “19. Yüzyıl Sonlarında Suriye ve Lübnan Üzerinde Bazı Notlar”, Osmanlı Araştırmaları, IV, İstanbul 1984, s. 89-90.

${ }^{2}$ Philip K. Hitti, The Syrians in America, New York 1924; İbrahim Serbestoğlu, Osmanlı Kimdir? Osmanlı Devleti'nde Tabiiyet Sorunu, İstanbul 2014, s. 282.

${ }^{3}$ Eliezer Tauber, "The Political Role of the Algerian Element in Late Ottoman Syria", International Journal of Turkish Studies, 5/12, 1990-1991, s. 27-45; İbrahim Serbestoğlu, "Osmanlı Suriye'sinde Cezayir Muhacirleri”, Geçmiş ve Gelecek Bağlamında Orta Doğu, İstanbul 2018, s.35-51.
} 
beş bin keseye ve diğerleriyle borçlanılarak harcanan paraların toplamının ise elli beş milyon kuruşa ulaştığını Maliye Hazinesine sunulan aylık cetvellerden tespit edilebiliyordu.

Vilayetin gelir ve gider açığı olmadığı, diğer vilayetlerden birçok akçe alındığı halde hac tertibi için dışarıdan yüzde on sekiz faiz ve ağır şartlarla her sene borçlanılmış ve borcun toplamı elli yedi milyon kuruşa ulaşmıştı. İhale ile iltizama verilen kaza ve köylerin bazıları hazineye sunulan ihale defterlerinden çıkarılmış ve bunların çıkarılma sebepleri araştırılmamıştır. Bazı mahallerde iltizam gelirlerinde mültezimlerin talepleri üzerine yaklaşık bir milyon kuruşa indirime gidilmişti. Hatta mültezimlerin çoğu kefalet senedi vermemiş, mezat pusulalarında yazılı bedel mültezim ve kefile mühürlememiş olduğundan öşür gelirlerinin davalara rağmen hazineye aktarılmamıştı.

Kazaların yönetimi hukuktan yoksundu. Kaza müdürünün başka bir göreve gidip, müdürlük görevini çocuklarına vekaleten bıraktığı sıklıkla görülen bir durumdu. Çocuklar, kazanın mali işlerini yönetip, resmi evrak düzenleyebiliyordu. Sahte evraklarla vilayet sınırlarına dahil edilmek suretiyle alım-satımı yapılmış ve yetkililerce de onaylanmış resmi işlemler gerçekleştirilmiştir.

Aralarında yabancı konsolosluk tercümanlarının da bulunduğu tefecilerin eline düşen köylüler borçlarını ödeyemeyince arazilerini kaybediyordu. Bir tefecinin milyonlarca kuruş talep ettiği görülebiliyordu. Çiftliklere dönüştürülen köylerin zamanla harap olması, ahalisinin toprakları terk etmesi siradan bir durumdu. ${ }^{4}$

Raporun ikinci bölümünde mali işlerinin yeniden tesisi, gelir ve giderlerinin dengelenmesi ve harcamaların kontrol edilmesi ile ilgili çalışmalar anlatılmış ve icmal tabloları ile yapılan harcamalar gösterilmiştir. Vilayetin gelir ve giderleri yeniden incelenip defterler hazırlanmıştı. Usule aykırı harcamalar kesilmişti. 1865/1281 yılından 1873/1289 yılının ortalarına kadarki tüm mali işlemler yeniden değerlendirildiği gibi beş ay içinde yeni harcama yönetimi oluşturulmuştu.

1874-1876 (1290, 1291 ve 1292) yıllarında düzenlenen sürre-i hümayun için borçlanma faizleri geçmiş yıllara göre daha düşük tutulmuştur. Giderlerin önemli kısmı vilayet gelir kalemlerinden sağlanmıştır. Hicaz Vilayetine beş bin, Banuk/Yanuk bölgesi için Beyrut Banuk/Yanuk halkına on dokuz bin ve Maliye Hazinesine yirmi dört bin lira gönderilmiştir.

Akçe iskontosu aranılması, mal sandıklarına teslim edilen paraların cinsi ve fiyatının yevmiyelerde gösterilmesi adet olunduğu halde 1874-1875 (1290-1291) senelerinde ayrıca iskonto defterleri tutulmuştur. Tutulan iskonto defterlerinde Şam Sancağında 1874/1290 senesinde üç yüz seksen küsur bin ve 1875/1291 senesinde dört yüz küsur bin kuruş iskonto geliri kaydedilmiştir. Bağlı livalardan iki sene içinde elde edilen iskonto gelirleri ise iki yüz bin kuruşa ulaşmıştır.

Yapılan araştırma ve soruşturma sonucu öşür vermediği belirlenen 114 köy ve mezra Esad Paşa'ya sunulan 20 Aralık 1874/8 Kânûn-i Evvel 1290 tarihli müzekkere üzerine öşre dahil edilerek dört yüz bin kuruş bedel ile ihalesi yapılmış ve durum nezarete bildirilmiştir.

\footnotetext{
${ }^{4} \mathrm{Bu}$ tür çatışmalar Osmanlı coğrafyasında sıklıkla görülmekteydi. Midhad Paşa'nın Tuna'da kurmaya çalıştığı Memleket Sandıkları sorunun çözümü için önemli bir başlangıçtı. Bkz: Seçil Akgün, "Midhad Paşa'nın Kurduğu Memleket Sandıkları: Ziraat Bankası'nın Kökeni”, Uluslararası Midhat Paşa Semineri Bildirileri ve Tartışmalar, Edirne 8-10 Mayls 1984, Ankara 1986, s. 185-211. Canik Sancağında da kredi müessesesinin henüz modernleşemediği yıllarda tefeciler adeta kol geziyor, köylüleri mağdur ediyordu. Bkz: İbrahim Serbestoğlu- Abidin Temizer, "Çiftçiyi Tefeciden Kurtarma Projesi: İkraz Sandıkları", $2^{\text {nd }}$ International Symposium on New Trends in Social and Liberal Sciences, Ankara 2017, s.543-560.
} 
Akka Sancağında senelerden beri vergi vermediği tespit edilen 17 köyden gereken vergilerin tahsili hakkında Vali Hamdi Paşa'ya 28 Şubat 1874/11 Muharrem 1291 tarihinde müzekkere sunulmuştur. Anılan köylerin 1874/1291 senesi öşür gelirlerinin altı yüz bin kuruş olduğu ve yıllık iki yüz bin kuruşa kadar vergi vermeleri gerektiği hesaplanmıştır.

Hama Sancağı Cebel-i Kelibe nahiyesinin sancaktan vilayete ve vilayetten Maliye Hazinesine gönderilen muhasebe ve ihale defterlerine konulmayan 1872/1287 senesi öşür gelirleri yüz seksen bin küsur kuruş olarak 1874/1289 senesi mal muhasebesinde yeniden gelir gösterilmiştir.

Kudüs tımarlılarından 14 neferin tımar vergileri hakkında Maliye Hazinesine sunulan mazbatanın hiçbir şekilde kayıt ve incelemelere dayanmadığ 1 halde düzenlendiği ortaya çıkarılmıştı. Bu konudaki araştırma ve soruşturma evrakı hazineye sunulmak üzere orta muhasebeye bırakılmıştır. Anılan mazbatada yazılı tımar vergilerinin yıllık yüz otuz bin toplamı toplamı bir milyon yüz küsur bin kuruştan ibaret olup bunun hakkında çekilen telgraflar Maliye Hazinesinde muhafaza altına alınmıştı.

Maaş ve gider senetleri incelendiğinde onay damgalarının sahte olduğu görülmüsstür. Yetkililer uyarılmış ve üç parçası Tahrirât Kalemine sözlü olarak bildirilip Maliye Nezaretine sunulmak üzere gönderilmiştir. Anılan evrakın senelerden beri vilayette bekletildiği tarihlerinden anlaşıllmıştır.

Vilayette görevli zaptiye askerlerinin maaş ve ücretlerini kayıtsız ve deftere yazılmaksızın on seneden beri kredi olarak aldıkları tespit edilmiştir. Memurların görevi olmamakla birlikte sorumluluktan kurtulmak için mal memurlarının yeniden müfredat defteri yazmaları için hükümetten izin alınmış ve Asakir-i Merkûme Heyeti defter ve özel senetler düzenlemeye alıştırılmış, ancak elli bin kese alacağa karşı gelen senetler ortadan kaldırılmıştır.

Vilâyette görevli gezici askeri birliğin ilk olarak oluşturulduğu 1865/1281 senesinden 1873/1289 senesi sonuna kadar alacak karşılığ yoluyla borçlanılan üç milyon küsur bin kuruşun bin beş yüz parça senetleri yok olmak derecesine gelmiş iken bunlar dört ay süresinde muhâsebesi görülerek düzenlenmiş defter Maliye Hazinesine sunulmuştur.

Önceki yönetim zamanındaki mal memurlarının iyi niyetleriyle rütbe terfileri yapılarak her biri birer memuriyete görevlendirilmiştir. Malların korunmasına hıyanet ettiklerine dair evrakı kanunsuzluğa ve genelin düşüncesine mukavemet ederek hazırlayan bir memurun çalışması yazışmalarla tasdik olunduğu halde ödüllendirilmesi dikkate alınmamıştır.

Raporun üçüncü bölümünde yaptıkları çalışmalar ile mali işler, gelir ve gider dengesinin tesisi ve 1slahı çalışmalarında görevlerini tam yapan memurların devletçe ödüllendirilmesi istenilmiştir.

Maliye Nezaretine gönderilen yazıdaki vilayetin maliye işleri ve kayıtlarının ıslahına muktedir defterdar talebi üzerine önceki Masârıfat-1 Umumiye Muhasebecisi Mecdüddin Efendi defterdar olarak tayin edilmiştir. Mecdüddin Efendi, ortaya koyduğu gayret ve sebat ile kısa bir sürede maliye ve hesap işlerini sslah etmiş ve kayıtları yeni yöntemlerle düzenleyerek vilayeti mali işleri düzenli vilayetler seviyesine çıkarmıştır. Emredilen işleri rahatlarına tercih ederek yapan memurların padişahın iltifatına mazhar olmaları gerektiğinden Mecdüddin Efendi'nin maaşının yüzde beş ilave edilerek üç bin kuruşa çıkarılması ve üçüncü rütbeden Mecidiye nişanı ile taltifi talep edilmiştir.

Telgraf ile bildirilen Sadrazam buyruğu gereği vilayet defterdarı İstanbul'a dönmüştür. Defterdarın Suriye'deki memuriyetinden beri Suriye vilayeti maliye işleri ve gelir giderinin düzeni ve iyileştirilmesi yolunda gerçekleştirdiği çalışma ve gayretin izleri gözle görülmüsstür. Defterdar, görevlerinde ve hazinenin mallarının korunması işinde gerçekten güzel hizmetleri, 
eserleri ve doğruluğu görülmüş olduğundan ödüllendirilmeyi hak etmiştir. Bakanlığa sözlü olarak iletilmek üzere defterdarın kendisine vilayetin gelir ve giderlerinin denkleştirilmesi ve maliye işlerine dair bazı yazılar tebliğ edilmiştir. ${ }^{5}$

\section{Sonuç ve Değerlendirme}

17. yüzyıldan itibaren değişim ve dönüşümünü Batı eksenli gerçekleştirmeye başlayan Osmanlı Devleti, hemen her alanda bu sürecin sancısını yaşıordu. Yeni muktedirler merkezi idarenin sarsılmasıyla oluşan boşlukları elde etmenin mücadelesini veriyorlardı. İktidar çatışması yalnız İstanbul'da değil, taşrada da yaşanıyordu. İlişki ağlarına ve otorite boşluğuna bağlı olarak yerel güçler veya devlet memurları kendi iktidar alanlarını oluşturuyorlardı. Osmanlı modernleşmesinin merkezileşme anlamına geldiği düşünüldüğünde merkezi hükümetin en büyük mücadelesi taşradaki bu güç odakları, kanıksanmış hale gelen hukuksuzlukla olduğu açıtır.

Suriye Vilayeti de diğer Osmanlı idari birimlerinden farklı değildi. Merkeze gönderilen raporlar taşranın fotoğrafını çekerken, değişimin ne denli zorlu koşullarda gerçekleştirilmeye çalışıldığını da ortaya koyuyordu. İşini yapmaya çalışan memur ve görevlilerin yaşadığı baskı ve yıldırma politikaları çoğu zaman başarıya ulaşıyordu.

\section{Kaynakça}

BOA, Y.EE.33/114.

Akgün, Seçil, “Midhad Paşa'nın Kurduğu Memleket Sandıkları: Ziraat Bankası'nın Kökeni”, Uluslararası Midhat Paşa Semineri Bildirileri ve Tartışmalar, Edirne 8-10 Mayıs 1984, Ankara 1986, s. 185-211.

Hitti, Philip K., The Syrians in America, New York 1924.

Ortayl1, İlber, "19. Yüzyıl Sonlarında Suriye ve Lübnan Üzerinde Bazı Notlar", Osmanlı Araştırmalart, IV, İstanbul 1984, s. 89-113.

Serbestoğlu, İbrahim - Abidin Temizer, "Çiftçiyi Tefeciden Kurtarma Projesi: İkraz Sandıkları”, $2^{\text {nd }}$ International Symposium on New Trends in Social and Liberal Sciences, Ankara 2017, s.543-560.

Serbestoğlu, İbrahim, "Osmanlı Suriye'sinde Cezayir Muhacirleri”, Geçmiş ve Gelecek Bağlamında Orta Doğu, İstanbul 2018, s.35-51.

Serbestoğlu, İbrahim, Osmanlı Kimdir? Osmanlı Devleti'nde Tabiiyet Sorunu, İstanbul 2014.

Serbestoğlu, İbrahim, Tanzimat, Teftiş ve Canik Sancağında Modernleşme, Ankara 2019.

Tauber, Eliezer, "The Political Role of the Algerian Element in Late Ottoman Syria", International Journal of Turkish Studies, 5/12, 1990-1991, s. 27-45.

\footnotetext{
${ }^{5}$ Osmanlı taşrasında benzer bir modernleşme sancısı ve süreci için bkz: İbrahim Serbestoğlu, Tanzimat, Teftiş ve Canik Sancağında Modernleşme, Ankara 2019.
} 


\section{TRANSKRIPSIYYON ${ }^{6}$}

Varak 1

Suriye vilâyet-i dâiresi vüs'at-i arâzi ve kuvve-i nebâtiyece birkaç vilâyete mu'âdil vâridâtının dahî o nisbette tezâyüd etmesi lâzım geleceği irade-i delail iken bir ehemmiyet ve ........... ............. kuvvetiyle orası kavânîn ve nizâmâtın icrâ-yı ahkâmından suret-i ğayr-1 resmiyede müstesnâ tutularak umûr-1 mâliyesi biraz vakitten berû ta'rîfi nâ kâbil bir hâle girmiş olmaktan nâşî şu hâlin islahıyla umur-1 mâliye-i vilâyetin yeniden te'sîsi ve tanzîmi emel (asıl) olmuş ise de k1lleti hasebiyle ta'yîni derece-i vücûbda görünen ve pek dûn bulunan ba'z1 memûrîn ma'âşâtı içün sarfa ................. istenilen mebâlığın hazinece 'ale'l'âde bütçede karşıllı̆̆ yoktur cevabıyla geçiştirilmesinden dolayı tekrâr isti'zân-1 cür'et olunamamasını teksir-i mahsûlât ve vâridâttan kat'-1 nazar mürettebât-1 sahîha-i hazineden eyâdi-i ihtilâsı ve kitmânda kalan birçok şeylerin meydana çıkarılmasına ve vâridât-1 devletten sene be sene külliyetlü mebâlığın zâyi` ve telef olmasına sebebiyet verdiği görülmüştür.

Ezcümle â'şâr ve vergisi suret-i kitmânda kalmış olan yüzotuz 'adedi mütecâviz karye ve mezra'anın meydana çıkarılmış olmasına göre canibimce ma'aşlarla müstekîm ve muktedir me'mûrîn istihdâm olunduğu halde daha pek çok vâridâtın meydana çıkarılacağı derkâr deyu vilâyetçe menâfi'-1 hazîne kasr-1 ma'âşât ve masârıfât cânibince bulunamayub sslâh-1 idâre ve taharri-i mektûmât ile husûlider olabileceğine ve az ma'aşla me'mûr istihdâmı sûretinin fâidesi intâc ideceği zâyi'âtın bindebir cüzüne tekâbül idemeyeceğine ber minvâl-i muharrer yüzotuz bu kadar karye ve mezra'anın mektûbetiyle bu babda şimdiye kadar ne vilâyetçe nede hazîne-i celîlece asla vukûf ve ma'lûmat bulunmaması ve aranub sorulmaması delil-i kâfi olabileceği irâde-i tezkârdır. Binâen 'aleyh bu babda vârid-i hâtır-1 'âcizânem olan ba'zı husûsâtın 'arz ve beyânını vakt-i âhire ta'lîk ile oranın idâresi hakkında meşhûdât-1 'âcizânem olan husûsâtta ba 'zılarının ya'ni şâyân-1 istiğrâb olanların 'alâ tarîkı'l-ihtisâr 'arz ve beyanına ibtidâr olunur.

$10 / 1$

JANUARY 2020
Şöyleki mu'âmelâtı nizâm-ı dâiresinde cereyân ettirmek ve mehmâ emken usule muvâfık defter tutmak şöyle dursun vâridât ve masârıfât-1 vilâyeti doğruca tesbît ve tahrîr etmek tarîkı bile iltizâm olunmadığından ne bir vâridâtın miktâr ve tahsîlâtına ve nede bir kaydın sıhhatine emniyet olabilür.

Halef ve selef beyninde teslîm ve tesellüm kâ'ide-i mültezeme ri'âyet olmadığı gibi eslâfdan ba'zıları muhâsebe kalemleriyle mal sandıklarının defâtir-i resmiyesini dahi berâber alub gitmiş ve hatta bir kazâ mal müdîrinin diğer bir hizmete girerek gûyâ hükümete haber vermeksizin yerine tevkîl eylediğini oğlu ma'rifetiyle o kazânın umûr-1 mâliyesini beş sene müddet idâre eylediği ve bu müddet zarfinda diğer hizmette bulunan merkûm babası mal müdîri tanılarak muâmelât-1 resmiye ânın nâmına kabul olunduğu görülmüştür.

Muhâsebe kalemleri yevmiyelerinde murakkam vâridât ve masârıfât sandık yevmiyelerinde muharrer vâridât ve masârıfatla tevâfuk ve tevâzün eylemediği misüllü kalem ve sandık yevmiyeleri beher yevm yekdiğeriyle karşılaştırılarak mal me'mur ve sandık eminleri tarafından temhir olunan umûr-1 mâliye nizâmnâmesi ahkâmından iken hiçbir yevmiye defterine sandık eminlerinin bile mühür koymağa tenezzül etmedikleri müşâhade edilmiştir.

Beher sene Â'şârı ihâle ve ilzâm olunan kazâ ve karyelerin hazîneye takdîm olunan ihâle defterlerinin ba'zılarından bilâ istîzân pek çok karyeler tay ve ihrâc olunduğu ve bunların sebebi ihrâcı hiçbir taraftan aranub sorulmadığı edilen tedkîkât üzerine tebyîn edilmiştir. Buna cür'et iden muhâsebe acaba daha neler yapmamıştır.

\footnotetext{
${ }^{6}$ BOA, Y.EE.33/114.
} 
Her nasılsa ba'zı hesabları rü'yet olunan sandık eminleri dörtyüzbin kuruşa kadar alacaklu çıkarılarak bu makûlelere haylice akçe derlediği ba'zı defterlerde görülmüştür. Buda hiçbir mahalde görülüb işidilmişmidir.

Sandıklara teslîm akçeler içün küçük ve büyük mal me'murlarının mührü ve işâreti olmaksızın yalnız sandık eminleri taraflarından mühürlü mühürsüz 'âdi makbuz pusulası verildiği ve vâridât-1 mukannenden ist'izân ve istinsâr edilmeksizin kilitlü akçe sarf olunduğu görülmüştür. Hatta oraca mal me'murlarının böyle bilâ ist'izân sarf eyledikleri mebâlığı yekûnu onbeşbin keseye ve diğerleriyle berâber takrîzan sarf olunan mebâlığın mecmû' ${ }^{6}$ ellibeş milyon kuruş resîde olunduğunu hazîne-i celîleye takdîm kılınan şehrî cetvelleri isbât ider.

Muvâzene-i vilâyetin açığı olmadığı ve sâir vilâyetlerden birçok akçe alındığı halde surre-i hümâyun denilen hac tertîbatı içün hâriçden yüzde onsekiz fâiz ve ağır şartlarla her sene kilitlü akçe istikrâz olunarak bu borcun yekûnu şimdiki halde elliyedi milyon kuruşa varmış ve miktârını mübeyyen tanzîm olunan müfredât defteri bundan bir çok sene evvel mâliye hazinesine takdim kılınmıştır.

Vilâyette müstahdem asâkir-i zabtiye ketebe defteri ve alay ve tabur mazbatası tanzim ve i'tâ itmeyerek ma'âş ve ta'yinatları 81 tarihinden 89 senesine kadar her neferin yedine verilen pusulalar mûcibince şundan bundan kırma sûretiyle alınmıştır. Ve sarâhaten dahî mal sandığından ahz ve istîfa eylemişlerdir.

Vâridât-1 devletten velev on para olsun bir miktârın tenzîli mutlaka irâde-i seniyye istihsâline mütevakkıf iken idârece ba'zı vâridât-1 maktû'a bedelâtından mültezimlerinin iddi'âsı üzerine bilâ istîzân her nasılsa bir milyon kuruşa karib akçe tenzil olunduğu görülmüştür.

Mültezimlerin pek çoğundan kefâlet senedi alınmamasından ve mezâd pusulalarında murakkam bedeli ne mültezim ve nede kefîle temhir ettirilmemesinden dolayı vâridât-1 'oşriyenin pek çok kalemleri da'vâlar altında kalub çürümüştür.

Mürâbahacıların kura ahalisine ikrâz eyledikleri mebâlığın hesâbına bakmak üzere mürâbahacılık iden konsolos tercümânlarından mürekkeb teşkil olunan Kura Komisyonunun hükm-i zâlimânesi üzerine pek çok karyeler arâzî-i ahâli yerlerinden çıkarak çiftlik hükmüne girmiş ve ba'zıları dahî külliyen harâb olarak ahâlisi şuraya buraya dağılmıştır. Hatta bu mürâbahacılardan birinin dört beş karyeden ma'a fâiz onbir milyon kuruşa karîb akçe taleb ve da'vâ itmekte idüğü görülmüştür.

Birçok sahte evrâk-1 sahîha senelerce vilâyet dâiresi dâhilinde alunub satılmış ve muhâsebelerce kabul olurda üzerlerine muâmelât-1 resmiye yürütülmüştür.

İşte ahvâl-i ma'rûzaya nazaran vâridât-1 hazinenin ne sûretle dûçâr-1 hasar olduğu anlaşılacağından tafsîlâtından sarf-1 nazar edilmiştir.

\section{İrâde-i Ahîra}

Müstağni-i arz ve beyân olunduğu üzere işin oluruyla çıkıştırılıvermesi geçmiş zamana tesâdüf olunduğundan oranın kâ'ide-i ğayr-1 meşrû'asına ve 'umûmun efkârına karşu mukâvemeti göze aldırarak müste 'înen bi-tevfîk-1 teâlâ işe bed' ve mübâşeretle vâridât ve masârıfat-1 vilâyet yeni baştan tetkik ve tahrîr ve defâtir-i cedîdeye tesbît ve tahrîr ile berâber bilâ irâde ve nizâma muğâyir sarfiyât kat' ve tevkif olunarak ve masârıfâtın 'umûmunu şâmil tanzim edilen müfredât defteri hazîne-i celîleye takdim kılınmış ve bu sûretle 81 târihinde teşkil olunub 89 senesi evâsıtına kadar umûr-1 mâliyesi 'acîb ve ğarîb bir halde idâre olunan bir vilâyetin üç beş mâh zarfında te'sîs-i umûr-1 mâliye ve hesâbiyesine muvaffak olunmuştur. 
Zamân-1 'âcizâneme tesâdüf iden 90 ve 91 ve 92 seneleri surre-i hümâyun denilen hac tertîb ve havâlâtı olan senevî seksensekizbin lira geçmiş seneler misüllü bir takım fâhiş fầizleriyle istikrâza ve mahall-i sâireden akçe celbine lüzum göstermeksizin sene be sene vilâyet emvâlinden tediye ve ibkâ edilmekle berâber geçmesine Hicâz vilâyetine beşbin ve Banuk / Yanuk havâlisi içün Beyrut Banuk teb'asına ondokuzbin ve mâliye hazînesine yirmidörtbin lira irsâl ve teslîm kılınmış ve Sûriyece şimdiye kadar görülmemiş bir idâre tarîkı açılmıştır.

54

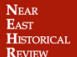

$10 / 1$

JANUARY

2020

İcmâl Lira

\begin{tabular}{|l|l|l|l|}
\hline \multicolumn{3}{|l|}{ Surre Denilen Tertîbâtına } \\
\hline \multirow{3}{*}{ Sene-i rakamiyedir. } & Sene 90 & 80000 & \multirow{2}{*}{230000} \\
\cline { 2 - 3 } & Sene 91 & 80000 & \\
\cline { 2 - 3 } & Sene 92 & 70000 & \\
\hline & 230000 & \\
& &
\end{tabular}

\begin{tabular}{|l|l|l|}
\hline \multicolumn{2}{|l|}{ Banuk Havâlisine } & \multirow{2}{*}{43000} \\
\hline Hazîne-i Celîleye & 24000 & \\
\hline Banuka & 19000 & \\
\hline \multirow{2}{*}{} & 43000 & 50000 \\
\cline { 2 - 3 } & Hicâz Vilâyetine & 278000 \\
\cline { 2 - 3 } & Kese \\
& 55600 \\
\hline
\end{tabular}

\section{Varak 2}

Akçe iskontosu aranılmak ve mal sandıklarına teslîm olunan mebâlığın cinsi ve fiyâtı yevmiyelerde gösterilmek Suriye vilâyetince 'âdet olunduğu halde zamân-1 'âcizânemde ayrica tutulan iskonto defterlerinde mukayyed olduğu üzere 90 senesinde Nefs-i Şam Sancağında üçyüzseksen küsur bin ve 91 senesinde dörtyüz küsur bin kuruşa iskonto hâsılâtı vukû‘ bularak ayrıca îrâd kayd kılınmış ve elviye-i mülhakanın şu iki sene zarfında vukû' bulan iskonto hâsılâtı dahî ikiyüzbin kuruşa varmıştır.

Olunan tahkîkât üzerine 'oşür virmediği netîce iden yüzondört karye ve mezr'anın 'oşre idhâli hakkında Es'ad Paşa merhûma takdîm eylediğim 8 Kânûn-i Evveline 90 târihlü müzekkire-i 'âcizânem üzerine kurâ ve mezâr1-'1 mezkûranın şimdilik dörtyüzbin kuruş bedel ile ihâlesi icrâ k1lınarak keyfiyeti Maliye Nezâret-i Celîlesine bildirilmiştir.

Akka Sancağında dahî onyedi karyenin sinîn-i vefîreden berû vergileri ketm ve ihfâ olunmakta idüğü meydâna çıarılarak îcâb iden vergilerinin tarh ve tahsîli hakkında Vâli-i Mesbûk Devletlu Hamdi Paşa hazretlerine 11 Muharrem sene 91 târihinde bir kit'a müzekkere takdim kılınmış ve kurâ-yı mezkûranın 91 senesi vâridât-1 'oşriyesi olan altıyüzbin kuruş tesbîtince senevî ikiyüzbin kuruşa kadar vergi vermeleri lâzım geleceği 'inde'l-hesâb anlaşılmıştır. 
Hama Sancağı dâhilinde kâin Cebel-i Kelîbe nâhiyesinin 87 senesi hâsılât-1 'oşriyesi olan mebâlı̆̆ ne sancaktan vilâyete gönderilen ve nede vilâyetten hazîne-i celîleye takdim kılınan ihâle ve muhâsebe defterlerine konulduğundan bunun miktâr-1 hâsılâtı olarak meydâna çıkarılan ğayr-1 ........ yüzseksenbin küsur kuruş 89 senesi mal muhâsebesinde müceddeden îrâd gösterilmiştir.

Kuds-i Şerîf tımarlularından ondört neferin tımar bedelâtı hakkında vilâyetten mâliye hazînesine takdim olunan bâlâsı mukarrerâtlu mazbatanın birgûne kuyûd ve tetkikata mesned olmadığ hallere bırakmaya ne ma'rifetiyle tanzim olunduğu meydâna çıarılarak dâhil-i kumpanya olan muhâsebe-i vilâyet mukayyedlerinden iki nefer efzâ tard ve muhâsebe muhbiri 'azl edilerek bu babda olan tahkîkât evrâkı hazineye takdîm olunmak üzere orta muhasebeye bırakılmıştır. Mezkûr mazbatada muharrer tımar bedelâtın seneviyesi yüzotuzbin terâkümi birmilyon yüz küsur bin kuruştan 'ibâret olub bunun hakkında çekilen telgrafnâmeler hazîne-i celîlede mahfuzdur.

İcmâl

\begin{tabular}{|l|l|l|}
\hline Vâridât-1 Cedîde & \multicolumn{2}{|l|}{} \\
\hline & İskonto Hâsılâtı & \\
\hline Şam Sandığ1 & 780000 & \multirow{2}{*}{80000} \\
\hline Elviye Sandıkları & 200000 & \\
\cline { 2 - 2 } & 980000 & \\
\cline { 2 - 3 } & &
\end{tabular}

\begin{tabular}{|l|l|}
\hline $\begin{array}{l}\text { Kurâ ve Mezâr1'in } \\
\text { 'Âşârı }\end{array}$ & 400000 \\
\hline $\begin{array}{l}\text { Kumpanya } \\
\text { Ma'rifetiyle } \\
\text { Yapılan } \\
\text { Mazbatada } \\
\text { Murakkam }\end{array}$ & 200000 \\
& 1580000 \\
\hline
\end{tabular}

\begin{tabular}{|l|l|}
\hline \multicolumn{2}{|l|}{ Sa'y-1 Hazîneye } \\
\hline $\begin{array}{l}\text { Defterlere Konmayan } \\
\text { Cebel-i Kel ‘Âşârı }\end{array}$ & 180000 \\
\hline $\begin{array}{l}\text { Kumpanya Ma'rifetiyle } \\
\text { Yapılan Mazbatada } \\
\text { Murakkam }\end{array}$ & \\
\hline Timar Bedelâtının......... & 1000000 \\
\hline & 2760000 \\
\cline { 2 - 2 } & Kese \\
\cline { 2 - 2 } & 5520 \\
\cline { 2 - 2 }
\end{tabular}


İşbu beşbinbeşyüz yirmi keseden başka vâridât-1 havâiyeden bir ellibin kuruş bakıyye meblağ daha îrâd kayd edilmiş ise de tafsîl-i keyfiyetten ihtirâzen anların tahrîrinden sarf nazar olunmuştur.

Maaş ve masraf senedâtı bi'z-zât tetkik idülür iken varaka-i sahîha tamgaları sahte birçok senedât görülerek keyfiyet sûret-i muharremânede vilâyete ihtâr ve üç kit'ası tahrîrâta leffen Mâliye Nezâret-i celîlesine takdim ve isrâ kılınmış ve evrâk-1 mezkûranın senîn-i vefîreden berû vilâyet dâiresi dâhilinde sorulmakta olduğu târihlerinden istidlâl kılınmıştır.

Vilâyette müstahdem asâkir-i zabtiyenin kayıtları olmadığı halde maaş ve ma'îşâtlarını on seneden beru bilâ defter 'ale'l-hesâb suretiyle takrîzan almakta oldukları görülerek gerçi mal me'murînin vazifesi değil ise de başımızı mesûliyetten kurtarmak içün bunlarında yeniden tahrî̀-i bi'l-icrâ bâb-1 'âli cânib-i sâmiyesine takdîm kılınan müfredât defteri üzerine irâdesi istihsâl kılınmış ve bu yüzden asâkir-i merkûme hey'eti defter ve senedât-1 mahsûsa tanzim itmeğe alıştırılmağla berâber ellibin keselik 'ale'l-hesâb senedâtı ortadan kaldırmıştır.

Vilâyette müstahdem asâkir-i müfreze-i seyyârenin bidâyeten teşkili olan seksenbir senesinden seksendokuz senesi nihâyetine kadar 'ale'l-hesâb tarîkıyla takrîzan almış oldukları üçmilyon küsur bin kuruşun binbeşyüz parça senedâtı hemen ğâib olmak derecesine gelmiş iken bunlara dört mah zarfında muhâsebesi bi'r-ru'ye tanzim edilen defteri hazîne-i celîleye takdim kılınmıştır.

İdâre-i sâbıka zamânında bulunan mal me'murlarının hüsn-ü insaflarında hiçbiri açıkda bırakılarak terfi'-1 rütbeleriyle berâber herbiri birer me'muriyetle kayırılmış oldukları halde vikâye-i emvâli hıyânete yoluna evrâkın akıllara hayret veren kâ'ide-i ğayr-1 meşrû'asına ve 'umûmun efkârına karşu münferiden iki buçuk sene mukâvemet eden 'âciz bir me'murun hüsnü hizmeti zîrde suretleri münderic muharreratla dahî tasdîk olunduğu hallere mükâfattan kat'-1 nazar altı mahdan berü kemâl-i ıztırâbla ye's ve fütûr içinde yaşamasına ağlamadan başka bir söz bulamadığından buracıkta hatm-i giftâr eyledim.

\section{Suriye Vilâyetinden Maliye Nezâret-i Celîlesine Tahrîrât Fî 27 Șevvâl Sene ......}

Vilâyetin muâmelât-1 mâliye ve kuyûdiyesinin lüzum-1 1slâhı cihetiyle muktedir bir defterdâr ta'yîni hakkında mesbûk olan 'arz ve iş'âr-1 'âcizânem üzerine masârıfât-1 'umûmiye muhâsebecisi sâbık sa'âdetlü Mecdüddin Efendi/ufuk ta'yîn ve i'zâm buyrulmasıyla buraya muvâsalât-1 'âcizânemde umûr-1 hesâbiye ve muâmelât-1 sâire hakikaten şâyân-1 teessüf bir halde görülmüş iken şu az bir müddette mûmâ ileyh bendeleri tarafindan umûr-1 mâliye ve mu'âmelât-1 hesâbiyenin sslâhı ve kuyûdâtın usûl-i cedîde vechile tanzîmi hakkında ibrâz olunan ikdâm ve ğayret şu vilâyeti şimdiki halde umûr-1 mâliyesi muntazam vilâyetler arasına götürerek doğrusu bu babda mûmâ ileyh isbât ehliyetiyle müstehakkın yeniden haklarında meşmûli var iken olan eltâf-1 seniyyeye kesb-i istihkâk ve kâbiliyet eylemiş ve bu misüllü masâlıh-1 me'mûralarının hüsn-i ............. huzûr ve istirâhat-1 zâtiyelerine tercih ve takdim ile izhâr-1 sarf ve istikâmete bezl-i mesâi iden bendegânın sâye-i mükâfâtüyle hazret-i mülûkânede mazhar-1 taltîfât olmaları hakkında yaptırdığı müse'adât-1 sâmiye-i nezâreteyn-i . ............. müsellahâttan bulunan olduğundan mûmâ ileyhin mahsûsu olan ma'aşının ba'zı emsâli vechiyle yüzde beşinin i'âdesiyle üçbin kuruşa iblâğ 1 ve üçüncü rütbeden bir k1t'a mecîdiye nîşân-1 zî şânı dahî 'nâyet ve ihsâniyle taltîfi husûsuna sezâvâri-i müsâde-i 'aliyye-i nezâretpenâhileri ........ cür'et olundu olbabda

Mehmed Halebî 
Suriye Vilâyetinden Maliye Nezâret-i Celîlesine Tahrîrât Fî 12 Sene 93

Bâ telgraf şerefvukû' bulan irâde-i 'aliyye-i cenâb-1 nezâretpenâhileri mucibince defterdâr-1 vilâyet sa'âdetlü efzâpenâhları dersa'âdete i'zâm olundu. Mûmâ ileyhin buraya me'muriyetinden beru Suriye vilâyeti umûr-1 mâliye ve hesâbiyesinin tanzim ve sslâh1 yolunda sarf eylediği mesâ‘î ve ğayretin âsâr-1 meşkûresi bu kere ra'yü'l-'ayn müşâhede olunmuş ve bu vilâyete me'muriyet-i çâkerânemden şimdiye kadar umûr-1 me'muresinde ve emvâl-i hazinenin muhâfazas1 emrinde cidden ve hakikaten hüsn-i hizmeti ve âsâr-1 ğayret ve istikâmeti görülmüş olduğundan i'tâf-1 celîle ve mükâfât-1 seniyyeye bi hakkın kesb-i liyâkat ve istihkâk eylemiş olduğunu ma'raz-1 tasdîk ve şahâdette 'arz u beyân ile eltâf ve 'inâyât-1 celîle-i cenâb-1 nezâretpenâhilerine mazhariyetle mesrûriyeti husûsuna müsâ'ade-i celîle-i bende perverîleri şâyân buyrulmasını hâssaten istirhâm ider ve vilâyetin muvâzene ve idâre-i umûr-1 mâliyesine dâir taraf-1 eşref-i asâfânelerine şifâhen 'arz olunmak üzere kendüsüne ba' $z 1$ mevâd / sevâd teblî̆g olunduğu cihetle ifâde-i ma'rûzanın hüsn-i tesviye-i 'icâbına dahî erzâne-i müsaâde-i 'aliyyelerini istid'â eylerim olbabda.

Ahmed Hamdi 


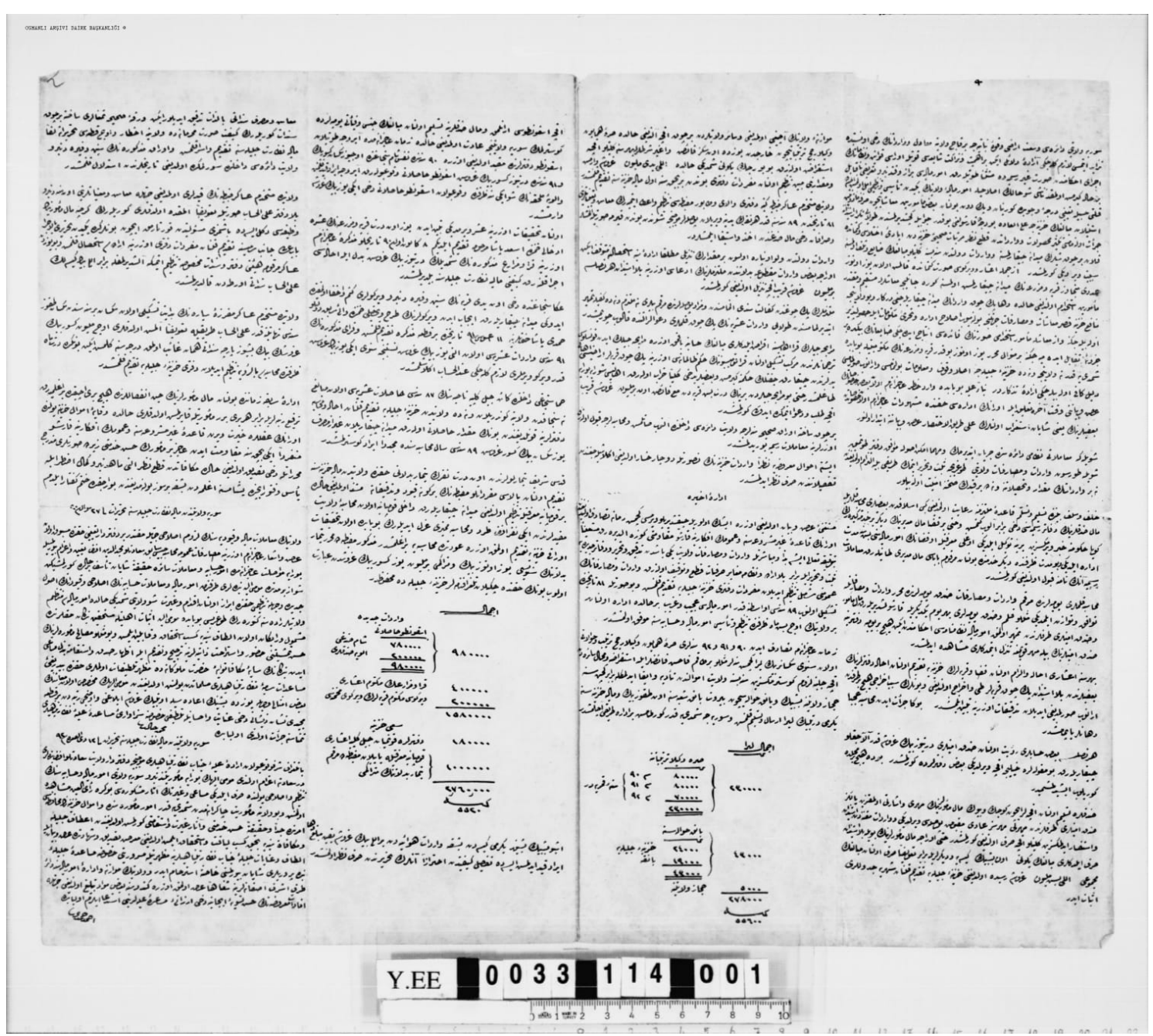

